\title{
Wanda Matras-Mastalerz
}

Instytut Nauk o Informacji

Uniwersytet Pedagogiczny im. KEN w Krakowie

e-mail:wmatras@up.krakow.pl

\section{Biblioterapia - ewolucja teorii i rozwój praktyki. Przegląd na podstawie doświadczeń polskich i zagranicznych}

\section{DOI: http://dx.doi.org/10.18778/0860-7435.22.23.03}

\begin{abstract}
Abstrakt: Artykuł stanowi próbę omówienia ewolucji teoretycznych podstaw biblioterapii oraz możliwości jej zastosowań praktycznych w działaniach z zakresu profilaktyki, terapii, wychowania, edukacji i socjalizacji czytelników. Atrakcyjność, ale i trudność opisywania biblioterapii łączy się z jej interdyscyplinarnością. Płynnie łączą się w jej obrębie literaturoznawstwo, bibliologia, psychologia, pedagogika, socjologia, filozofia, historia, antropologia, a nawet nauki medyczne. Zróżnicowane, a jednocześnie bliskie zagadnienia, połączone wspólnym mianownikiem przynależności do refleksji humanistycznej, mogą przekształcić się w poręczny zestaw elastycznych narzędzi przydatnych w procesie umacniania kondycji psychicznej i fizycznej odbiorców.
\end{abstract}

Słowa kluczowe: biblioterapia, funkcja terapeutyczna literatury, czytelnictwo, umacnianie zdrowia psychicznego, wsparcie emocjonalne 


\section{Wstęp}

Kanadyjski literaturoznawca Herman Northrop Frye zbudował teorię naukową ujmującą literaturę jako jednolity, ponadczasowy i autonomiczny system symboli, który w drodze ewolucji literackiej prowadzi od form najprostszych do arcydzieła. Według autora, literatura jest przemieszczona, czyli przystosowaną do wymogów wiarygodności i etyczności mitologia, która może kształtować psychikę odbiorcy (Frye, 1957, 1977; por. Baluch, 2008, s. 7). Ten porządek znajduje zastosowanie zarówno w tekstach dla dzieci i młodzieży, jak i w książkach adresowanych do dorosłych czytelników. Literatura może prowadzić odbiorcę do własnych przemyśleń, wsparcia zdrowia psychicznego i fizycznego oraz zmiany postawy wobec siebie i innych.

Prezentowany artykuł jest próbą omówienia zarówno teoretycznych podstaw biblioterapii, jak i jej zastosowań praktycznych poprzez przykłady tzw. dobrych praktyk. Wskazuje możliwości wykorzystania literatury w procesie „umacniania” czytelnika i osiagania poczucia dobrostanu. Właściwie dobrane do indywidualnych lub grupowych odbiorców teksty moga stać się elementem działań z zakresu profilaktyki, terapii, wychowania, edukacji i socjalizacji. Biblioterapia to nie tylko czytanie tekstu, ale także różnorodne metody i formy pracy z nim w celu wspierania rozwoju i osiagania lepszej jakości życia.

Zarówno atrakcyjność, jak i trudność opisywania biblioterapii wiąże się z jej interdyscyplinarnością. Płynnie łączą się w jej obrębie literaturoznawstwo, bibliologia, psychologia, pedagogika, socjologia, filozofia, etyka, historia, antropologia, a także nauki medyczne. $Z$ tej przyczyny biblioterapia była omawiana najczęściej z punktu widzenia dyscyplin współtworzących i odmawiano jej scjentystycznego charakteru (Czernianin et al., 2014; Szulc, 2011a). Z drugiej strony, połączenie zróżnicowanych, a jednocześnie bliskich zagadnień, należących do refleksji humanistycznej, może stanowić potencjał do przekształcenia się w zestaw elastycznych narzędzi, nadać siły i skuteczności tak „obudowanej” i wzmocnionej dyscyplinie. Aby tak się stało, konieczne jest jednak określenie naukowych i praktycznych ram biblioterapii oraz wypracowanie struktury, metod i jezzyka odpowiadajacych wymogom stawianym samodzielnym dyscyplinom naukowym (Kawoń-Noga, 2013).

\section{Wymiary biblioterapii w ujęciu aksjologicznym. Przegląd publikacji}

Biblioterapia, będąc procesem dynamicznego oddziaływania zachodzącego pomiędzy osobowością czytelnika a literatura, odbywającego się w licznych uwarunkowaniach psychosocjopedagogicznych, stała się przedmiotem refleksji naukowej wielu badaczy (Shrodes, 1950; Rubin, 1978). W Polsce biblioterapię spopularyzowano w latach 60. i 70. XX wieku dzięki publikacjom Wan- 
dy Kozakiewicz (1968, 1977), Danuty Gostyńskiej (1969, 1976, 1984), Juliana Aleksandrowicza (1973), Wandy Krzemińskiej (1973) oraz Teresy Stańczyk (1979). Po 1980 pojawiły się naukowe opracowania Wity Szulc (1984, 1994, 2001, 2011) oraz prace Ewy Tomasik, która w 1988 r. opublikowała obszerną recenzję anglojęzycznej książki Rhei Joyce Rubin Bibliotherapy sourcebook. Na szczególne wyróżnienie zasługuja publikacje Ireny Boreckiej (1992, 2002, 2004, 2008), która przyczyniła się do założenia (w 1997 r.) i rozwoju Polskiego Towarzystwa Biblioterapeutycznego we Wrocławiu. Z biegiem lat poszerzyła się liczba osób zainteresowanych tematyką terapii poprzez książki, także w ośrodkach akademickich (Zybert, 2000; WoźniczkaParuzel, 2002; Krasoń, 2004; Kruszewski, 2006; Matras-Mastalerz, 2011; Cyrklaff, 2014). Obecnie, liczba związanych z biblioterapią publikacji w książkach i czasopismach oraz materiałach elektronicznych, organizowane konferencje naukowe, kursy i szkolenia, wreszcie poświęcone jej zagadnieniom dwa czasopisma, uprawniaja do stwierdzenia, że biblioterapia stała się w Polsce „modna” i popularna. Niebagatelną rolę w propagowaniu idei biblioterapii odgrywaja publikacje na łamach kwartalnika „Biblioterapeuta. Biuletyn Informacyjnego Polskiego Towarzystwa Biblioterapeutycznego”, ukazującego się od 1998 r. pod redakcją Krystyny Hrycyk oraz półrocznika naukowego: „Przegląd Biblioterapeutyczny" wydawanego od 2011 r. przez Instytut Psychologii Uniwersytetu Wrocławskiego pod redakcją Wiktora Czernianina. W obydwu periodykach zamieszczane sa rozprawy, artykuły, scenariusze zajęć, odnoszace się zarówno do teorii, jak i działań praktycznych z zakresu biblioterapii klinicznej i wychowawczej. Ponadto, Polskie Towarzystwo Biblioterapeutyczne zorganizowało we Wrocławiu dwie międzynarodowe konferencje naukowe: „Biblioterapeuta w poszukiwaniu tożsamości zawodowej” (18 kwietnia 1997 r.) oraz „O potrzebie zawodu biblioterapeuty” (26 października 2012 r.). Sesje związane z biblioterapią inicjowały również inne polskie instytucje, głównie biblioteki naukowe, publiczne, szkolne i pedagogiczne, najczęściej pod auspicjami stowarzyszeń bibliotekarskich, co zadecydowało o ich ujęciu pragmatycznym. Spotkania te miały najczęściej formę warsztatów i były okazją do wymiany pomysłów w ramach tzw. dobrych praktyk.

$\mathrm{Na}$ międzynarodowych i ogólnopolskich konferencjach naukowych odbywających się w ośrodkach akademickich problematyka biblioterapii pojawiała się często, ale w charakterze specjalności wspomagającej inne dyscypliny naukowe, głównie pedagogikę, psychologię, bibliologię i literaturoznawstwo (Szulc, 2011b; Woźniczka-Paruzel, 2012). Z drugiej strony, sama terapia przez sztukę, do której wielu badaczy zaliczyło wspomaganie leczenia przy pomocy książek, boryka się z problemem nieuznawania jej jako autonomicznej nauki (Szulc, 2011b; Matras-Mastalerz, 2012a; Czernianin, 2014; Rudowski, 2014). 


\section{Wanda Matras-Mastalerz}

W toczącej się od wielu lat dyskusji nad statusem biblioterapeuty (Borecka, 2008; Czernianin, 2008; Matras-Mastalerz, 2012a) podkreśla się pierwotne znaczenie terminu „terapia”, który używany był w szerokim kontekście jako „troszczenie się”, „wspieranie”, „leczenie”, „opieka”, ,zajmowanie się”, „służenie" i uwypuklał pomoc profesjonalisty (terapeuty) w przebiegu procesu terapeutycznego. Biblioterapeuta, jako pośrednik i profesjonalny przewodnik, winien być albo lekarzem-psychologiem z dodatkowym przygotowaniem literaturoznawczym, albo bibliotekarzem, nauczycielem wykształconym $\mathrm{w}$ dziedzinie medycyny, psychologii i terapii.

W przekonaniu autorki niniejszego artykułu stworzenie jednego wzorcowego modelu działań biblioterapeutycznych nie jest możliwe ze względu na rozległość zakresu i zasięgu samej biblioterapii. Próby tworzenia modelu zależne były od dyscypliny wyjściowej, z punktu widzenia której proces biblioterapeutyczny miał być stosowany (Ippoldt, 2003). W badaniach literaturoznawców najistotniejszą rolę odegrała sztuka słowa, literatura, i z tej perspektywy trafniej byłoby za Janem Trzynadlowskim (1982) używać określenia „literaturoterapia” tj. „leczenie literacką zawartością książki”.

Z kolei pedagodzy odwoływali się do koncepcji biblioterapii „rozwojowej”, opartej na modelu psychodynamicznym oraz zachęcali do przyjęcia strategii dydaktycznych mających charakter behawioralny (Tomasik, 1994).

W analizach bibliotekoznawczych, w procesie biblioterapii poważną rolę odegrała strona bibliologiczna, elementy książki, które współpracuja z zawartością tekstową (Zybert, 2000; Woźniczka-Paruzel, 2001). Teoretycy i praktycy psychoterapii wskazywali, że celem biblioterapii (podobnie jak psychoterapii) jest rozwój osobowości człowieka, a metoda, która pozwala najpełniej korzystać z pomocy książki, jest psychoterapia racjonalna, polegająca na wyjaśnianiu pacjentom istoty ich dolegliwości i schorzeń oraz krzewieniu zasad higieny psychicznej (Szulc, 2001; Czernianin et al., 2012). W działaniach tych pomocna okazywała się odpowiednio dobrana lektura z zakresu oświaty zdrowotnej, psychologii społecznej, socjologii, seksuologii, pedagogiki rodzinnej, a także filozofii. Socjologowie spoglądali na biblioterapię przede wszystkim od strony aktywności i upodobań czytelniczych, zajmując się np. badaniami preferencji lekturowych osób chorych, niepełnosprawnych, niedostosowanych społecznie, seniorów itp. (Ippoldt, 2003). Dokonując próby formułowania wniosków wynikających z dotychczasowych rozważań, należy raczej mówić o „modelach”, a nie o jednym, wspólnym „modelu” postępowania biblioterapeutycznego, natomiast zadaniem biblioterapeuty jest zaproponowanie takiego typu pracy (programu terapeutycznego), aby przeżycia 
związane z lektura pomogły odbiorcy zaakceptować stan, w którym się znajduje lub przyczyniły się do próby podjęcia aktywności w dążeniu do zmiany (Borecka, 2008; Matras-Mastalerz, 2012b, 2013).

\section{T Przykłady dobrych praktyk w procesie umacniania zdrowia poprzez biblioterapię}

W procesie terapii przy pomocy literatury istotną rolę odgrywa pośrednik, biblioterapeuta, korzystający z metod wypracowanych przez psychoterapię, ale skupiający się głównie na doborze i wykorzystaniu odpowiedniej literatury w pracy z czytelnikiem. Istota ludzka jako jedność biopsychospołeczna potrzebuje zarówno zdrowej „somy”, jak i prawidłowo funkcjonującego „psyche”. Profesor Jerzy Woy-Wojciechowski, wieloletni prezes Polskiego Towarzystwa Lekarskiego, w Przedmowie do książki Być lekarzem, być pacjentem. Rozmowy o psychologii relacji (Eichelberger et al., 2013) napisał, że ,jest taki rodzaj leku, który podaje się przez ucho: to nadzieja i dobre słowo". Słowa wypowiadane i zapisane moga wspierać, dodawać sił i wiary w możliwość przezwyciężenia trudności, wzmacniać, podnosić na duchu, działać niczym balsam, ale potrafią też ranić, być powodem doznawania przykrości i smutku. Wsparcie za pomoca ukierunkowanego czytelnictwa może stanowić przydatne narzędzie wspomagające higienę psychiczną człowieka oraz jego rozwój osobisty (Krzemińska, 1973; Cyrklaff, 2014).

Pojawiające się w literaturze przedmiotu określenie „książki na receptę” (Books on Prescription) używane było raczej w znaczeniu metaforycznym. Ciekawą i godną zaszczepienia na gruncie polskim inicjatywą wydają się działania amerykańskiej organizacji non-profit Reach Out, and Read (ROR), założonej w 1989 r. w szpitalu w Bostonie przez lekarzy pediatrów: Barrego Zuckermana i Roberta Needlmana oraz pedagoga dziecięcego Kathleen Fitzgerald -Rice. ROR dzięki środkom otrzymanym z Amerykańskiego Departamentu Edukacji od 2001 r. dostarcza około 6 mln. książek rocznie do 4500 klinik i ośrodków zdrowia w USA. Mali pacjenci oraz ich rodzice prócz tradycyjnych metod leczenia objęci zostali programem promocji czytelnictwa. Podczas pobytu w placówce leczniczej moga bezpłatnie korzystać ze zgromadzonej literatury, a w kolejnym etapie, opuszczając mury szpitala, otrzymuja „receptę" z wykazem ksiązek zalecanych do przeczytania oraz kilka nowych egzemplarzy sugerowanych w spisie pozycji (Pinker, 2015). Oczywiście należy pamiętać, że nie istnieja recepty uniwersalne, odpowiednie dla wszystkich, jednak potencjał tkwiący w opowieściach może stać się skutecznym środkiem terapeutycznym dla czytelników w każdym wieku, którzy właśnie przy pomocy książek zdołają, być może, odnaleźć „receptę na życie” (Matras-Mastalerz, 2012b). 
Etymologia wyrazu „biblioterapia” (gr. biblion - książka, therapeia - pomoc, leczenie, przywracanie zdrowia) wskazuje na jego funkcję i treść, czyli zastosowanie lektury książek jako środka wspomagającego leczenie. Sam termin został wprowadzony w 1916 r. przez Amerykanina Samuela McChorda Crothersa, który w artykule zatytułowanym $A$ Literary Clinic, wydrukowanym w „Miesięczniku Atlantyckim” opisał możliwości stosowania książek w leczeniu chorych (Rubin, 1978b). Późniejsi badacze używali także innych określeń w celu uwypuklenia potencjału terapeutycznego tekstu.

W literaturze anglojęzycznej, oprócz terminu bibliotherapy, pojawiły się również: reading therapy, therapy through literature, bibliolinking, literatherapy, poetry therapy, bibliohelp, zaś w publikacjach polskich pisano o leczeniu książka, terapii czytelniczej, bibliopsychologii, czytelnictwie terapeutycznym, czytelnictwie ukierunkowanym, logoterapii oraz literaturoterapii (obejmującej węższe zakresowo: poezjoterapię, bajkoterapię i baśnioterapię).

Podstawy biblioterapii stworzył rosyjski bibliotekarz i bibliograf Nikołaj A. Rubakin, który od 1919 r. w Instytucie Bibliopsychologii w Lozannie zapoczątkował badania w zakresie terapeutycznych możliwości oddziaływania literatury i indywidualnej recepcji czytelników, propagując czytelnictwo w procesie samokształcenia (Ankudowicz, 1960). Pierwsza definicja biblioterapii ukazała się w 1941 r. w Ilustrowanym Stowniku Medycznym Dorlanda (i była konsekwentnie przedrukowywana w późniejszych jego wydaniach) charakteryzując ten rodzaj terapii jako „wykorzystanie książek i ich czytanie w leczeniu chorób nerwowych" (Rubin, 1978b). Jednak wielu badaczy (Głombiowski et al., 1983; Borecka, 1992; Czernianin, 2008) wskazywało na fakt, że historia biblioterapii sięga czasów antycznych, bo przecież już starożytni Grecy nazywali swoje biblioteki „lecznicami duszy” (psyches jatrejon), co opisał w swoim dziele historyk i podróżnik Diodor z Sycylii, autor czterdziesto-tomowego dzieła Bibliotheca historica (Szulc, 2011a). Owo „lekarstwo dla duszy" zainspirowało polskiego bibliofila ks. Leopolda Szersznika, który na początku XIX w. ufundował bibliotekę publiczną w Cieszynie i polecił ozdobić fronton jej gmachu identycznie brzmiącym napisem.

\section{【Afirmacja sensu życia i próby osiągania jego lepszej jakości w kontek- ście biblioterapii}

Jaki sens ma nasze życie? Czy można cieszyć się nim pomimo pojawiających się trudności i dramatów? Czym jest „dobre życie” lub jego brak? Jak wypracować w sobie pozytywną postawę i zgodę na różnorodność i nieprzewidywalność życia? Te i inne pytania stawiaja sobie uczestnicy zajęć biblioterapeutycznych poświęconych wzmacnianiu afirmacji życia i osiaganiu 


\section{Biblioterapia - ewolucja teorii...}

poczucia dobrostanu. Aby wspomaganie leczenia poprzez literaturę mogło być skuteczne, odbiorcy potrzebuja troski i wsparcia przewodnikabiblioterapeuty w wyzwalaniu doznań i przeżyć poprzez wartości tkwiące w książkach. Takim działaniom poddawane są między innymi osoby cierpiące z powodu niskiej samooceny, w tym ludzie przewlekle chorzy, niepełnosprawni, borykający się ze stanami depresyjnymi i zwykłym spadkiem dobrego samopoczucia. Afirmacja w terapii poprzez tekst służy przede wszystkim „przeprogramowaniu” czytelnika w celu osiągnięcia zamierzonych rezultatów. Stefan Szuman w Afirmacji życia podkreślał, że „sens życia jako immanentna jego treść przeżywany jest wtedy, gdy wzbudza ono ciekawość i zainteresowanie człowieka, gdy wzrusza go do głębi, gdy jest tajemnica, którą pragnie objać, zrozumieć i zgłębić" (1938, s. 5). Afirmacja wykorzystuje mechanizm autosugestii w celu wzmacniania poczucia akceptacji u osoby ją stosującej. Postawa taka opiera się na założeniach „biofilii”, przez którą Erich Fromm rozumiał miłość życia, przedkładanie w stosunkach międzyludzkich radości, empatii, asertywności nad pesymizmem, niepewnością czy egoizmem. Biofil, w myśl teorii niemieckiego filozofa, to człowiek, który kocha życie, jest pełen ciepła, zaraża optymizmem, jest otwarty na nowe doświadczenia (Fromm, 1971, 1994). Poznając siebie, staje się bardziej tolerancyjny dla swoich i cudzych wad. Dojrzała afirmacja życia jest aktywnym działaniem, realizowaniem marzeń, celów i zadań, doskonaleniem osobistych cnót i zalet, a także troską o własny rozwój duchowy (Seligman, 2005). Wpisane jest w nią nie tylko zadowolenie i optymizm, ale również dostrzeżenie sensu cierpienia (Haidt, 2007). Afirmację życia można pojmować też jako wierność i przywiązanie do wartości, które współtworzą kulturę i cywilizację. Ludzie, postępując zgodnie z owymi wartościami, nadają sens swojemu życiu (Szuman, 1938).

Angielska pisarka Margaret Silf w zbiorze opowiadań zatytułowanym W poszukiwaniu madrości życia (2005) zamieściła opowieść Tylko nasiona. Główny bohater, wyruszył w podróż w poszukiwaniu pokoju, radości i miłości. Wędrując, spotykał jednak głównie choroby, wojny, kłótnie, odrzucenie i podziały. Odwiedzał miejsca, w których ludzie im więcej posiadali, tym bardziej byli do siebie wrogo nastawieni, im więcej musieli bronić, tym mocniej atakowali. Tęskniąc za pokojem, szykowali się do wojny. Marząc o miłości, otaczali się murem braku zaufania i barierami lęku. Tęskniąc za życiem, pogrążali się w śmierci. Pewnego ranka wędrowiec wszedł do sklepu, w którym sprzedawca zadeklarowal posiadanie wszystkiego, czego tylko pragnie. Pielgrzym głęboko się zamyślił, bo przecież tyle życzeń chciałby zrealizować: „Pragną pokoju dla swojej rodziny, narodu i świata, chciał zrobić coś dobrego w swoim życiu, marzył aby chorzy wyzdrowieli, a samotni mieli przyjaciół, aby głodni mieli dość jedzenia, aby każde dziecko otrzymało szansę by się 
kształcić, aby wszyscy na Ziemi żyli ciesząc się wolnością" (Tamże, s. 162163). Kiedy opowiedział o tych wszystkich oczekiwaniach, sklepikarz zamyślił się na chwilę i odpowiedział: „Przepraszam, powinienem był od razu wyjaśnić. Nie mamy tu owoców, tylko nasiona...” (Tamże, s. 163). Każdy człowiek otrzymał w życiu (i wciąż dostaje) takie „osobiste ziarna” i to od niego zależy, które z nich zakiełkuja, wyrosną i wydadzą owoce, a które zapomniane, może wciąż czekają na swój czas... Czasami w pielęgnowaniu nasion pomaga mu ktoś bliski, należący do rodziny lub będący przyjacielem, bywa też, że „motorem napędowym” staje się osoba spotkana przypadkowo lub postać pełniąca rolę nauczyciela, terapeuty czy psychologa. Wzrost, zmianę, może także spowodować zasłyszana historia lub przeczytana książka. Ważne, by mieć świadomość, że osoby (także fikcyjne postacie literackie), sytuacje, wydarzenia, działania, posiadaja moc wpływania na życie człowieka, wzbogacaja je i zmieniaja. Ale przecież bywa i tak, że ingerencji innych osób w nasze życie nie oceniamy dobrze, czasami mamy do nich żal za brak lub nadmiar zainteresowania. „Jesteś tym, co pamiętasz i co czujesz” napisała we wstępie do swojej książki psychoterapeutka Ewa Woydyłło (2014, s. 8-9) przekonując, że w życiu towarzyszy nam „dobra i zła pamięć” i że tę złą można zamienić w dobra poprzez świadomą, wewnętrzną transformację prowadzącą do uświadomienia sobie, nazwania, uzewnętrznienia i pozbycia się niechcianych emocji.

Marek Aureliusz, cesarz rzymski, stoicki filozof żyjący w II wieku naszej ery, Ksiege Pierwszq swoich Rozmyślań (1997) poświęcił w całości wyznaniom „co komu zawdzięcza”. Wymienia tam kilkunastu krewnych, nauczycieli i przyjaciół, dzięki którym wiele się nauczył, „posiadł liczne przymioty” i cechy charakteru:

„Dziadkowi Werusowi - [zawdzięczam] łagodność i równe usposobienie. Ojcu umiłowanie skromności i charakter męski. Matce - ducha pobożności i dobroczynności oraz odrazę nie tylko przed wyrządzaniem krzywdy, lecz i przed myślą o niej. Nadto, sposób życia prosty, daleki od zbytku ludzi bogatych. Pradziadowi żem do szkoły publicznej nie chodził, lecz miał dobrych nauczycieli w domu [...]. Wychowawcy - wytrwałość w trudach i przykładanie ręki do pracy i niezajmowanie się zbyt wielu sprawami naraz. Rustykowi - zrozumienie potrzeby poprawy i pielęgnowania charakteru. [...] Apolloniuszowi - niezależność sądów i rozważna pewność w postępowaniu. [...] Sekstusowi - ducha życzliwości. I zrozumienie życia według natury. I powagę niewymuszona. I zdolność troskliwego odgadywania potrzeb przyjaciół. [...] Aleksandrowi ze szkoły Platona - zrozumienie, aby często i bez koniecznej potrzeby nie mówić i w listach nie pisać do kogo ,jestem zajęty” i aby w ten sposób, powołując się na okoliczności, nie uchylać się od obowiązku udzielania pomocy należnej bliźnim. [...] Bratu memu Sewerowi - miłość rodziny, prawdy i sprawiedliwości. [...] Bogom - że miałem dobrych dziadków, dobrych rodziców, dobrą siostrę, dobrych nauczycieli, dobrych domowników, krewnych, przyjaciół, prawie wszystkich [...]" (Aureliusz, 1997, s. 5-9). 
Cytowane powyżej dzieło rzymskiego filozofa, wykorzystywane często w pracy biblioterapeutów, przybiera chwilami formę medytacji, ćwiczeń duchowych, fragmentami przypomina testament i do dzisiaj swą siłą wyrazu i głębią spojrzenia inspiruje czytelników do refleksji nad miejscem człowieka w świecie. Z Ksiegi Pierwszej wynika, że cesarz miał nie tylko świadomość, że właściwie wszystko komuś zawdzięczał, ale także doceniał to, czuł wdzięczność i radość, że spotkał w swoim życiu takich ludzi. Działania biblioterapeutyczne, wzmacniające afirmowanie sensu życia, stymulują rozwój osobisty odbiorców terapii, którzy poprzez akceptację swoich zachowań, niedoskonałości oraz próbę zrozumienia i uszanowania odmienności innych, stają się bardziej dojrzali duchowo, świadomi, wdzięczni i szczęśliwi.

\section{Badania efektywności działań biblioterapeutycznych}

Odpowiedź na fundamentalne pytanie: jak słowo pisane oddziałuje na ludzką psychikę, inspirowało badaczy od czasów najdawniejszych. W dziełach Platona i Arystotelesa odnajdziemy liczne wątki poruszające tę tematykę (Szczeklik, 2003; Sinko, 2006). Badaczy roli literatury w terapii interesowała zaś głównie skuteczność stosowania tekstu określona i potwierdzona empirycznie. Wielu autorów wskazywało na liczne trudności pojawiające się podczas prób tworzenia własnych metod, sposobów i strategii określania efektywności pracy z tekstem (Rogers et al., 1997; Szulc, 1994; Tomasik, 1994; Woźniczka-Paruzel, 2002; Molicka, 2011; Czernianin et al., 2014; Cyrklaff, 2014; DymelTrzebiatowska, 2014). Opierając się na teorii modelu reagowania na literaturę, opracowanej przez Normana Hollanda (1989), zainspirowanej założeniami psychoanalizy literackiej Carla Gustawa Junga (1981) i Zygmunta Freuda (1982, 1996), uzupełnionej spostrzeżeniami Michaela Steiga (1989), należy zauważyć, że utwór literacki może oddziaływać na czytelnika na dwóch poziomach: z jednej strony trafia do nieświadomości człowieka poprzez formę, która działa na wzór psychicznych mechanizmów obronnych, z drugiej - poprzez znaczenie, które zostaje odczytane przez indywidualne ego (Dymel-Trzebiatowska, 2014). Społeczna użyteczność biblioterapii wydaje się niepodważalna, stąd rosnące zainteresowanie jej wykorzystywaniem praktycznym, i tym trudniejsze wydaje się naukowe badanie jej efektywności i skuteczności zastosowania.

Zmiany zachodzące u uczestników sesji biblioterapeutycznych mogą być nieuchwytne w natychmiastowej ocenie, ponieważ najczęściej dokonują się z opóźnieniem i sa widoczne dopiero po zakończeniu terapii. Sam odbiorca nie zawsze od razu uświadamia sobie „czy” i „co” się w nim zmieniło podczas kontaktu z dziełem. Utrudnia to biblioterapeutom weryfikowanie skuteczności swoich działań. Literatura umacnia, zapewniając doświadczenia zastępcze 


\section{Wanda Matras-Mastalerz}

poprzez opis, dialog, refleksję dotyczącą wydarzeń, a tym samym umożliwiając wsparcie emocjonalne, informacyjne, instrumentalne, a także duchowe (Molicka, 2008). Owo umacnianie czytelnika (empowerment), będące głównym celem pracy biblioterapeutów, to wyposażanie go w kompetencje, umiejętności i uprawnienia w procesie pełniejszego rozwoju, wspieranie jego potencjalnych zdolności oraz dodawanie sił w osiaganiu celów (Anczewska et al., 2007; Kociołek, 2012). Umacnianie stanowi nieodłączny element procesu zdrowienia. Możemy wyróżnić dwa aspekty umacniania: indywidualny dotyczący samoświadomości oraz strukturalny czyli instytucjonalno-społeczny. W biblioterapii klinicznej działania terapeuty $\mathrm{w}$ zakresie profilaktyki, leczenia i rehabilitacji są częścią rehabilitacji kompleksowej (Szulc, 1994). Irena Szmid w Psychologicznej analizie czynników wptywajacych na proces rehabilitacji podkreśliła, że „za efekt rehabilitacji uznać można zadowolenie osoby rehabilitowanej, będące stanem psychicznym najbardziej wzmacniającym motywację do dalszego działania" (1979). Za wskazówkę w poszukiwaniu właściwej metody badania skuteczności terapii można uznać także oparte na rozumieniu humanistycznym, stwierdzenie polskiego filozofa i socjologa Floriana Znanieckiego, który pisał, że „podstawowym materiałem empirycznym dotyczącym jakiejś ludzkiej aktywności jest doświadczenie samej osoby działającej, uzupełnione doświadczeniem tych, którzy reagują na jej działania, powtarzaja je lub w nich uczestniczą" (Znaniecki, 1936; Szacki, 1986).

Indywidualne, subiektywne odczucia, wynikające z kontaktów z książka, zarówno uczestników terapii, jak i biblioterapeutów, były mierzone najczęściej poprzez różnorodnie konstruowane kwestionariusze oceny, ankiety i wywiady oraz sondaże czytelnicze (Woźniczka-Paruzel, 2002; Borecka, 2008; Szulc, 2011a; Cyrklaff, 2014). W literaturze przedmiotu pojawiły się również krytyczne głosy dotyczące poszukiwania wyników badań statystycznych dokumentujących skuteczność terapii poprzez książkę. Według M. Molickiej „terapia przez literaturę piękną jest indywidualnym jej przetwarzaniem, zatem nieporozumieniem jest szukanie uogólnień w postaci wyników badań statystycznych, ponieważ jej oddziaływanie jest bardzo jednostkowo zindywidualizowane i wielowymiarowe" (2010).

Ciekawej próby stworzenia „Skali Pomiaru Umacniania” osób chorujacych psychicznie dokonały E. Sally Rogers, Judi Chamberlin oraz Marsha Langer Ellison w 1997 roku. W ocenie autorki niniejszego artykułu narzędzie to może być z powodzeniem stosowane w badaniach skuteczności biblioterapii klinicznej, a także (po wprowadzeniu niewielkich modyfikacji) w biblioterapii ogólnorozwojowej (humanistycznej). Obejmuje ono pięć obszarów: samoocenę i kształtowanie poczucia własnej wartości, wyposażenie w siłę i możliwość wywierania wpływu na teraźniejszość i przyszłość, świadome 


\section{Biblioterapia - ewolucja teorii...}

kontrolowanie wydarzeń, rozwój gotowości do działań środowiskowych, ale i umiejętność wyznaczania własnej autonomii oraz zdolność zachowań asertywnych i wyrażania społecznego sprzeciwu (Rogers et al., 2007).

Zakładając, że biblioterapia to metoda rozwoju osobistego, w której za pomocą odpowiednio dobranych materiałów wspiera się funkcjonowanie człowieka, możemy śmiało wpisać ją w szerszą strategię rehabilitacji psychologicznej i psychiatrycznej. Wspieranie chorego w trudnym okresie przystosowania do nowych, niepomyślnych warunków, także w kolejnych kryzysach emocjonalnych i interpersonalnych, to podstawowe zadanie terapeuty (Pużyński, 1993). Niewatpliwie biblioterapeuta i lekarz sa sojusznikami w walce z chorobą człowieka. Lekarz leczy choroby psychosomatyczne i psychiczne, natomiast biblioterapeuta zajmuje się „chorobami duchowymi”, korzystając z odpowiedniej literatury (Hora, 1986; Skorny, 1988; Kociołek, 2012). Dobór tekstów wymaga dużej wiedzy i doświadczenia w pracy z osobami potrzebującymi wsparcia. W 2004 r. w Stanach Zjednoczonych Dale Elizabeth Pehrsson i Paula S. McMillen z Uniwersytetu Stanowego w Oregonie opracowały kwestionariusz pytań do systematycznej ewaluacji książek uwzględniający ocenę lektur przydatnych w procesie terapii. Narzędzie to omówione w artykule A bibliotherapy evaluation tool (2005) obejmowało tematykę, przeznaczenie, kontekst sytuacyjny, stopień trudności tekstu oraz określenie zastosowania terapeutycznego. Zapoznając się z propozycjami tego typu należy pamiętać, że literatura stanowi początek, wyjście do oddziaływań terapeutycznych stymulując występowanie emocji oddziałujących korzystnie na proces zdrowienia (recovery) oraz przeciwdziałając powstawaniu emocji niepożądanych (Hora, 1986; Skorny, 1988). Książka jest pretekstem do spotkania z człowiekiem, także z samym sobą i w tej odważnej konfrontacji tkwi jej najgłębszy potencjał umacniający i terapeutyczny, nawet jeśli nie zawsze da się go precyzyjnie zmierzyć i opisać.

\section{Uwagi końcowe}

L Janusz Dunin w monografii Pismo zmienia świat. Czytanie. Lektura. Czytelnictwo napisał, że „do wartości terapeutycznej książki trzeba przekonywać jedynie tych, którzy nie zetknęli się z biblioterapią osobiście, ani nie poznali możliwości jakie ona stwarza" (1998, s. 62). Badacze zajmujący się terapią poprzez książkę wypracowali już odpowiednie modele biblioterapii, wyjaśnili pojęcia, pokazali jak stosować ją w praktyce, co jednak nie zmieniło faktu, że jest ona postrzegana wciąz jako nowa, rozwijająca się dopiero dziedzina. W istocie, ewolucja praktyki biblioterapeutycznej wymaga dalszego prowadzenia ilościowych i jakościowych badań naukowych w celu udowodnienia i udokumentowania skuteczności terapii poprzez literaturę. Aby proces 


\section{Wanda Matras-Mastalerz}

terapeutyczny przebiegał poprawnie i przynosił oczekiwane efekty, potrzebny jest profesjonalnie przygotowany pośrednik, biblioterapeuta, „przewodnik” po świecie książek. Obcowanie z dziełem literackim może mieć właściwości terapeutycznie wtedy, gdy pomiędzy utworem a odbiorcą zajdą relacje opierające się na trzech zasadniczych funkcjach: sprawiającej przyjemność, łagodzącej napięcie psychiczne oraz prowadzącej do rozwoju (przemiany). Książki moga stanowić remedium na indywidualne problemy emocjonalne i prowadzić do pozytywnego przewartościowania negatywnych doświadczeń poprzez dostarczanie wzorców osobowych oraz treściowych matryc do interpretacji.

\section{Bibliografia}

Aleksandrowicz, Julian. (1973). Literatura a zdrowie społeczeństwa. WarszawaKraków: PWN.

Anczewska, Marta \& Roszczyńska-Michta Joanna. (2007). O umacnianiu pacjentów w procesie zdrowienia. W: M. Anczewska, J. Wciórka (red.), Umacnianie, nadzieja csy uprzedzenia (s. 45-82). Warszawa: Instytut Psychiatrii i Neurologii.

Ankudowicz, I. (1960). Nikołaj A. Rubakin. Bibliotekarz, 11/12, 345.

Aureliusz, Marek. (1997). Rozmyślania. Warszawa: Państwowy Instytut Wydawniczy.

Baluch, Alicja. (2008). Od form prostych do arcydzieła. Wyktady, prezentacje, notatki, przemyślenia o literaturze dla dzৃieci i młodzৃieży. Kraków: Wydaw. Naukowe Akademii Pedagogicznej.

Borecka, Irena. (1992). Biblioterapia - nowa szansa ksiażki. Olsztyn: Wyższa Szkoła Pedagogiczna w Olsztynie.

Borecka, Irena. (2002). Biblioterapia w edukacji czytelniczej $i$ medialnej w sqkole podstawowej $i$ gimnazjum. Materiaty dydaktyczne dla naucrycieli $i$ bibliotekarzy. Wałbrzych: Wydaw. Państwowej Wyższej Szkoły Zawodowej im. Angelusa Silesiusa.

Borecka, Irena. (2004). Z motylem w tle: o baśni w biblioterapii $i$ terapii pedagogicznej. Wałbrzych: Wydaw. Państwowej Wyższej Szkoły Zawodowej im. Angelusa Silesiusa.

Borecka, Irena. (2008). Biblioterapia formq terapii pedagogicznej. Wałbrzych: Wydaw. Państwowej Wyższej Szkoły Zawodowej im. Angelusa Silesiusa.

Borecka, Irena. (2010). Magia Ogrodów. Kraków: Impuls.

Borecka, Irena \& Ippoldt, Lidia. (1998). Co çytać aby tatwiej radzić sobie w syciu czyli wprowadzenie do biblioterapii. Wrocław: Państwowe Pomaturalne Studium Kształcenia Animatorów Kultury i Bibliotekarzy we Wrocławiu.

Borecka, Irena \& Wontorowska-Roter, Sylwia. (2003). Biblioterapia w edukacji dziecka niepetnosprawnego intelektualnie. Materiaty dydaktyczne dla naucsycieli $i$ biblioteka$r z y$. Wałbrzych: Unus.

Crothers, Samuel M. (1916). A Literary Clinic. The Atlantic Monthly, 118(3), 291-301. Cyrklaff, Magdalena J. (2014). Biblioterapia w edukacji z zakresu profilaktyki uzale $\dot{z}-$ nień i promocji zdrowia. Toruń: Wydaw. Naukowe Uniwersytetu Mikołaja Kopernika. Czernianin, Wiktor. (2008). Teoretyczne podstawy biblioterapii. Wrocław: Wydaw. Atut. 


\section{Biblioterapia - ewolucja teorii...}

Czernianin, Wiktor \& Czernianin Halina. (2012). Psychologia literatury w świetle biblioterapii. Przeglad Biblioterapeutyczny, 2 (1), 5-42.

Czernianin, Wiktor \& Czernianin Halina. (2013). Metodologia badań biblioterapeutycznych. Rekonesans. Przeglad Biblioterapeutyczny, 3 (1), 7-15.

Czernianin, Wiktor \& Czernianin, Halina. (2014). Biblioterapia jako autonomiczna nauka. Rozważania wstępne. Przeglad Biblioterapentyczny, 4 (1), 11-34.

Dunin, Janusz. (1998). Pismo zmienia świat. Czytanie. Lektura. Czytelnictwo. Warszawa-Lódź: PWN.

Dymel-Trzebiatowska, Hanna. (2014). W poszukiwaniu odrobiny pocieszenia. Biblioterapeutyczny potencjat utworów Astrid Lindgren z perspektywy narratologii i psychoanalizy literackiej. Gdańsk: Wydaw. Uniwersytetu Gdańskiego.

Eichelberger, Wojciech \& Stanisławska, Irena A. (2013). Być lekarzem, być pacjentem. Warszawa: Czarna Owca.

Freud, Zygmunt. (1982). W stęp do psychoanalizy. Warszawa: PWN.

Freud, Zygmunt. (1996). Objaśnienia marzeń sennych. Warszawa: Wydaw. KR.

Fromm, Erich. (1971). O squtuce miłości. Warszawa: Państwowy Instytut Wydawniczy.

Fromm, Erich. (1994). Niech sie stanie czlowiek. Z psychologii etyki. WarszawaWrocław: PWN.

Frye, H. Northorp. (1957). Anathomy of Criticism. Four essays. New Jersey: Princeton University Press.

Frye, H. Northorp. (1977). Mit, fikcja i przemieszczenie. Tł. E. Muskat-Tabakowska. W: M. Głowiński, H. Markiewicz (red.), Studia z teorii literatury. Archiwum przekładów „Pamiętnika Literackiego”. T. 1 (s. 289-307). Wrocław: Zakład Narodowy im. Ossolińskich.

Głombiowski, Karol \& Szwejkowska, Helena. (1983). Ksiażka rekopiśmienna i biblioteka w staro żytności i średniowieczu. Warszawa: PWN.

Gostyńska, Danuta. (1969). Bibliotekarstwo i biblioterapia w szpitalu. Poradnik Bibliotekarza, 36(5), 149-151.

Gostyńska, Danuta. (1976). Terapia czytelnicza jako jedna z metod psychoterapii klinicznej. Szpitalnictwo Polskie, 20(4), 183-186.

Gostyńska, Danuta. (1984). Terapia wielkiego ładu. Kraków-Wrocław: Wydaw. Literackie.

Haidt, Jonathan. (2007). Szczęście. Gdańsk: Gdańskie Wydaw. Psychologiczne.

Holland, Norman. (1989). The dynamics of literary response. New York: Columbia University Press.

Hora, Zbigniew. (1986). Niektóre aspekty biblioterapii w wieloprofilowej terapii osób niepełnosprawnych. Twórczość $i$ sztuka $w$ życiu i rehabilitacji osób niepełnosprawnych. Wrocław: Wrocławski Oddział Polskiego Towarzystwa Walki z Kalectwem.

Ippoldt, Lidia. (2003). Biblioterapia w związkach z innymi naukami. Annales Academiae Paedagogicae Cracoviensis. Studia Ad Bibliothecarum Scientiam Pertinentia II, 9, 293-306.

Jung, Carl G. (1981). Archetypy i symbole. Warszawa: Spółdzielnia Wydawnicza „Czytelnik”.

Kawoń-Noga, Dagmara. (2013). Działania biblioterapeutyczne a zadania bibliotek pedagogicznych - wybrane zagadnienia. Modelowe Nauczanie. Opolski Przeglad Edukacyjiny, 1, 4-5. 
Kociołek, Roksana. (2012). Biblioterapia osób chorujących psychicznie - możliwości zastosowania. W: K. Hrycyk (red.), O potrzebie biblioterapii (s. 113-123). Wrocław: Państwowe Pomaturalne Studium Kształcenia Animatorów Kultury i Bibliotekarzy.

Kozakiewicz, Wanda. (1968). Csytelnictwo chorych. Warszawa: Stowarzyszenie Bibliotekarzy Polskich.

Kozakiewicz, Wanda. (1977). Biblioterapia w teorii i praktyce. Przeglad Biblioteczny, $47(1), 41-48$.

Kozakiewicz, Wanda \& Brzózka, Bożena. (1984). Biblioteka szpitalna dla pacjentów. Warszawa: Stowarzyszenie Bibliotekarzy Polskich.

Krasoń, Katarzyna. (2004). Wymiary biblioterapii ekspresyjnej - kilka refleksji wprowadzających. W: K. Krasoń, B. Mazepa-Domagała (red.), Ekspresja twórcza dziecka. Konteksty - inspiracje - obszary realizacji (s. 367-379). Katowice: GWSH.

Kruszewski, Tomasz. (1999). Książka jako narzędzie terapeutyczne. Wychowanie na co dzień, 1/2,12-13.

Kruszewski, Tomasz. (2006). Biblioterapia w działaniach placówek opiekuńczo-wychowawcrych. Torun: Wydaw. Uniwersytetu Mikołaja Kopernika.

Krzemińska, Wanda. (1973). Literatura piekna a zdrowie psychiczne. Warszawa: Państwowy Zakład Wydawnictw Lekarskich.

Matras-Mastalerz, Wanda. (2011). Zaczytaj się zdrowo! Lecznicza moc lektur dla dzieci, młodzieży i rodziców. Annales Universitatis Paedagogicae Cracoviensis. Studia Historicolitteraria XI, 101, 21-38.

Matras-Mastalerz, Wanda. (2012a). Biblioterapeuta i jego warsztat biblioterapeutyczny. W: K. Hrycyk (red.), O potrzebie biblioterapii (s. 43-60). Wrocław: Państwowe Pomaturalne Studium Kształcenia Animatorów Kultury i Bibliotekarzy.

Matras-Mastalerz, Wanda. (2012b). Książki na receptę, recepta na życie. W: I. Socha, A. Lakomy (red.), Lektury pokoleniowe $i$ ponadpokoleniowe. $Z$ zagadnień recepcji (s. 145-158). Katowice: Wydaw. Uniwersytetu Sląskiego.

Matras-Mastalerz, Wanda. (2013). Czytanie najskuteczniejszą metodą wychowawczą. W: B. Niesporek-Szamburska, M. Wójcik-Dudek (red.), Nowe opisanie świata. Literatura $i$ sztuka dla dzieci $i$ mtodzięzy w kregach oddziatywan (s. 155-168). Katowice: Wydaw. Uniwersytetu Śląskiego.

Molicka, Maria. (2008). Terapeutyczne funkcje literatury. Cripta Comeniana Lesnensia, 6, 27-40.

Molicka, Maria. (2010). Terapeutyczna rola literatury w paradygmacie psychologii kognitywnej. W: M. Kocójowa (red.), Biblioteki, informacja, ksiażka: interdyscyplinarne badania i praktyka w XXI wieku (s. 234-239). Kraków: ePublikacje Instytutu INiB UJ.

Molicka, Maria. (2011). Biblioterapia i bajkoterapia. Rola literatury w procesie zmiany rozumienia świata spotecznego i siebie. Poznań: Media Rodzina.

Pehrsson Dale, Elisabeth \& McMillen, Paula S. (2005). A bibliotherapy evaluation tool: Grounding counselors in the therapeutic use of literature. The Arts in Psychotherapy, 32 (1), 47-59. 


\section{Biblioterapia - ewolucja teorii...}

Rogers, E. Sally \& Chamberlin, Judi \& Ellison, Marsha L. (1997). A consumerconstructed scale to measure empowerment among users of mental health services. Psychiatric Services, 48(8), 1042-1047.

Rubin, Rhei Joyce. (1978a). Using bibliotherapy. A guide to theory and practice. London: Oryx Press.

Rubin, Rhei Joyce. (1978b). Przedmowa. W: R. J. Rubin (red.), Bibliotherapy Sourcebook (p. 4-12). London: Phoenix Oryx Press.

Rudowski, Tomasz. (2014). Studia nad arteterapia w ujeciu aksjologiczno-psychologicznym. Warszawa: Difin.

Shrodes, Caroline. (1950). Bibliotherapy: a theoretical and clinical-experimental study. Berkeley: University of California.

Shrodes, Caroline. (1960). Bibliotherapy. An application of psychoanalytic theory. American Image, 17, 310-318.

Shrodes, Caroline. (1978). A theoretical and clinical experimental study. W: R. J. Rubin. Using bibliotherapy. A guide to theory and practice (s. 23-28). London: Oryx Press.

Silf, Margaret. (2005). Tylko nasiona. W: M. Silf. W poszukiwaniu madrości życia. 100 opowiastek z. catego świata (s. 162-163). Warszawa: Zysk i S-ka.

Sinko, Tadeusz. (2006). Tray poetyki klasyczne: Arystoteles, Horacy, Pseudo-Longinos. Wrocław: Ossolineum.

Skomy, Zbigniew. (1988). Emocje a korekcyjna funkcja biblioterapii. W: Z. Skomy, J. Szocki, S. Zawistowski (red.), Małe formy metodyczne. Bibliotekoznawstwo (s. 1-9). Wrocław: Oddział Doskonalenia Nauczycieli,.

Stańczyk, T. (1979). Metody biblioterapii. Sapitalnictwo Polskie, 23(6), 275-278.

Steig, Michael. (1989). Stories of reading: subjectivity and literary under standing. Baltimore: Johns Hopkins University Press.

Szacki, Jerzy. (1986). Znaniecki. Warszawa: Wiedza Powszechna.

Szczeklik, Andrzej. (2003). Katharsis. O uzdrowicielskiej mocy natury i sztuki. Kraków: Znak.

Szmid, Irena. (1979). Psychologiczna analiza czynników wptywajacych na przebieg rehabilitacji. Warszawa: Centralny Związek Spółdzielni Rolniczej.

Szulc, Wita. (1984). Człowiek chory i książka. Bibliotekarz, 51(9/10), 228-233.

Szulc, Wita. (1994). Kulturoterapia. Wykorazystanie sz̨tuki i dz̨iatalności kulturalno-oświatowej w lecznictwie. Poznań: Wydaw. Akademii Medycznej w Poznaniu.

Szulc, Wita. (2001). Sztuka w stų̇bie medycyny: od antyku do postmodernizmu. Poznań: Wydaw. Akademii Medycznej w Poznaniu.

Szulc, Wita. (2011a). Arteterapia. Narodziny idei, ewolucja teorii, rožój praktyki. Warszawa: Difin.

Szulc, Wita. (2011b). Biblioterapia. Powrót do źródeł. Præeglad Biblioterapentyczny, 1(1), $6-29$.

Szuman, Stefan. (1938). Afirmacja śycia. Lwów: Lwowska Biblioteczka Pedagogiczna.

Tomasik, Ewa. (1988). Materiały źródłowe do biblioterapii. Recenzja książki pod red. R. J. Rubin. „Bibliotherapy sourcebook”, Oryx Press, London. Szkoła Specjalna, 1, 4-6.

Tomasik, Ewa. (1990). Możliwości zastosowania biblioterapii w pedagogice specjalnej. Bibliotekarz Olsætyński, 1, 29-36. 
Tomasik, Ewa. (1994). Caytelnictwo i biblioterapia w pedagogice specjalnej. Warszawa: Wyższa Szkoła Pedagogiki Specjalnej im. M. Grzegorzewskiej.

Tomasik, Ewa. (1997). Biblioterapia jako jedna z metod pedagogiki specjalnej. W: E. Tomasik (red.), Wybrane zagadnienia z pedagogiki specjalnej (s. 81-89). Warszawa: Wyższa Szkoła Pedagogiki Specjalnej im. M. Grzegorzewskiej.

Trzynadlowski, Jan. (1982). Biblioterapia jako problem teoretyczny i praktyczny. Zagadnienia wybrane. W: J. Trzynadlowski. Sztuka stowa i obrazu. Studia teoretycznoliterackie (s. 445-452). Wrocław: Zakład Narodowy im. Ossolińskich.

Trzynadlowski, Jan. (1990). Biblioterapia - złudzenia i nadzieje. Arteterapia II. Zeszyty Naukowe Akademii Muzycznej we Wrockawiu, 52, 3-4.

Woydyłło, Ewa. (2014). Dobra pamieć, zła pamięć. Warszawa: Wydaw. Literackie.

Woźniczka-Paruzel, Bronisława. (2001). Biblioterapia w Polsce i jej przemiany na tle rozwoju teoretycznych koncepcji światowych. W: B. Woźniczka-Paruzel (red), Biblioterapia $i$ caytelnictwo w środowiskach osób niepelnosprawnych. Zbiór studiów (s. 13-28). Toruń: Wydaw. Uniwersytetu Mikołaja Kopernika.

Woźniczka-Paruzel, Bronisława. (2002). Biblioterapia w środowisku wspótuzależnionych z. grup rodzinnych Al-Anon (od teorii do diriatań praktycznych). Toruń: Wydaw. Uniwersytetu Mikołaja Kopernika.

Woźniczka-Paruzel, Bronisława. (2012). Kierunki badań z zakresu biblioterapii w Polsce i zagranica - porównania i refleksje. W: K. Hrycyk (red.), O potrze ebie biblioterapii (s. 11-28). Wrocław: Państwowe Pomaturalne Studium Kształcenia Animatorów Kultury i Bibliotekarzy.

Znaniecki, Florian. (1936). Social Actions. New York: Farrar \& Rinehart.

Zybert, Elżbieta B. (2000). Ksiazki, które pomagaja żý: rewalidacyjna i terapentyczna funkcja ksiazki w zaktadach opieki zdrowotnej i spotecznej. Warszawa: Stowarzyszenie Bibliotekarzy Polskich.

\title{
Bibliotherapy - evolution theory and practice development. Overview on the basis of the Polish and foreign experiences.
}

\begin{abstract}
This article attempts to discuss the evolution of the theoretical basis of bibliotherapy and the possibility of its practical applications in the activities of prevention, treatment, education and socialization of readers. Its attractiveness, and at the same time difficulty of description, is connected with its interdisciplinary nature which smoothly combines study of literature, bibliology, psychology, pedagogy, sociology, philosophy, history, anthropology, and even medical sciences. This melting pot of so differentiated, yet similar issues is joined by their affiliation to humanistic reflection, and thus becomes a set of flexible tools useful in the process of strengthening the physical and mental condition of customers.
\end{abstract}

KEYWORDS: bibliotheraphy, the therapeutic function of literature, reading, strengthening mental health, emotional support 